\title{
Life-saving necklace: collateral circulation from the conus artery to the anterior descending artery
}

Naszyjnik ratujący życie - krążenie oboczne od tętnicy stożka do gałęzi przedniej zstępującej

\author{
Fatih Cam², Hasan Gungor'1, Mustafa Unal'2, Ufuk Eryilmaz ${ }^{3}$ \\ 1Department of Cardiology, Aydın Medline Hospital, Aydın, Turkey \\ 2Department of Cardiovascular Surgery, Aydın Medline Hospital, Aydın, Turkey \\ 32Department of Cardiology, Adnan Menderes University, Aydın, Turkey
}

Postep Kardiol Inter 2013; 9, 1 (31): 109-110 DOI: 10.5114/pwki.2013.34037

\begin{abstract}
We report a case of hyperacute inferior myocardial infarction with life-saving collateral circulation from the conus artery to the left anterior descending artery.
\end{abstract}

Key words: conus artery, collateral circulation.

\section{Streszczenie}

W pracy przedstawiono przypadek nadostrego zawału ściany dolnej serca z ratującym życie krążeniem obocznym z tętnicy stożka do gałęzi przedniej zstępującej.

Słowa kluczowe: tętnica stożka, krążenie oboczne.

Collateral circulation is important in preserving ventricular function, especially in coronary artery disease with total occlusion. The conus branch of the right coronary artery (RCA) has the capacity of angiogenesis and arteriogenesis [1, 2]. We report a case of hyperacute inferior myocardial infarction with life-saving collateral circulation from the conus artery to the left anterior descending artery (LAD). A 54-year-old man was referred to the emergency room with hyperacute inferior myocardial infarction. Coronary angiography demonstrated chronic total occlusion of the LAD at its proximal segment and acute total occlusion of the RCA at the proximal segment after the conus branch (Figure 1). The LAD was filled by the collateral circulation through a large conus artery that originated within the right sinus of Valsalva, very close to the ostium of the RCA. It coursed with the LAD at the medial segment (Figure 2). The circumflex artery was normal. Primary percutaneous transluminal coronary angioplasty of the occluded RCA was performed and one drug-eluting stent $(2.75 \mathrm{~mm} \times 30 \mathrm{~mm})$ was implanted. Coronary artery bypass graft surgery was recommended for revascularisation of the LAD.

Collateral circulation is an important factor in the pathophysiology of coronary artery disease. The symptoms and prognosis among these patients depend on the quality of the collateral circulation. This case shows the importance of collateral supply of conus branch circulation preventing cardiogenic shock in patients with chronic occlusion of the LAD and acute occlusion of the RCA.

\section{References}

1. de Agustín JA, Marcos-Alberca P, Hernández-Antolín R, et al. Collateral circulation from the conus coronary artery to the anterior descending coronary artery: assessment using multislice coronary computed tomography. Rev Esp Cardiol 2010; 63: 347-351.

2. Yamagishi M, Haze K, Tamai J, et al. Visualization of isolated conus artery as a major collateral pathway in patients with total left anterior descending artery occlusion. Cathet Cardiovasc Diagn 1988; 15: 985-988.

\section{Corresponding author/Adres do korespondencji:}

Hasan Gungor MD, Department of Cardiology, Aydın Medline Hospital, 09100 Aydın, Turkey, tel.: +90 (256) 212 00 12, mobile: +90 5068892238 , fax: +90 (256) 22525 41, e-mail: drgungorhasan@yahoo.com

Received: 18.10.2012, accepted: 8.11.2012. 


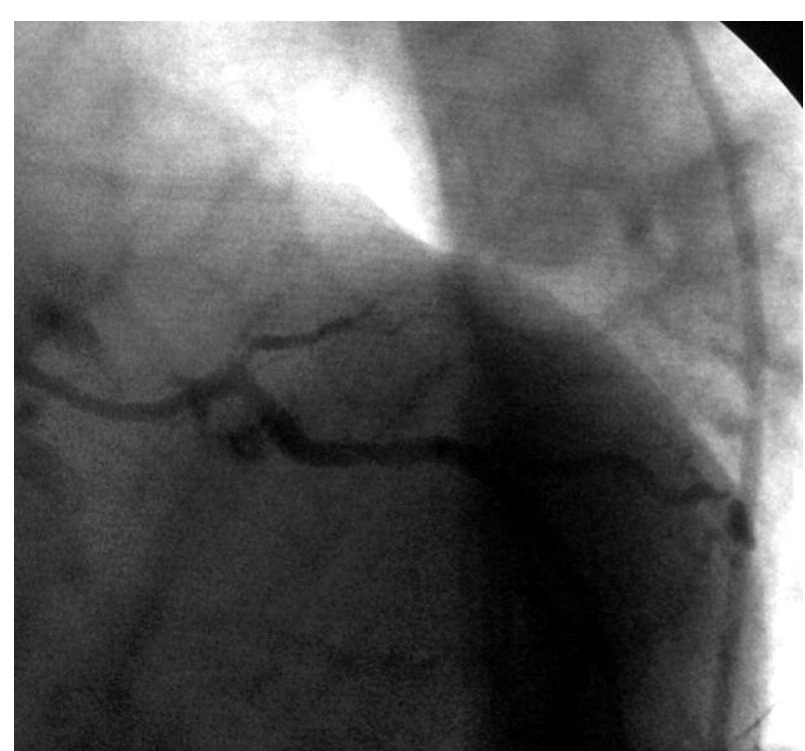

Fig. 1. Chronic total occlusion of left anterior descending artery

Ryc. 1. Przewlekle niedrożna gałą́ przednia zstępująca

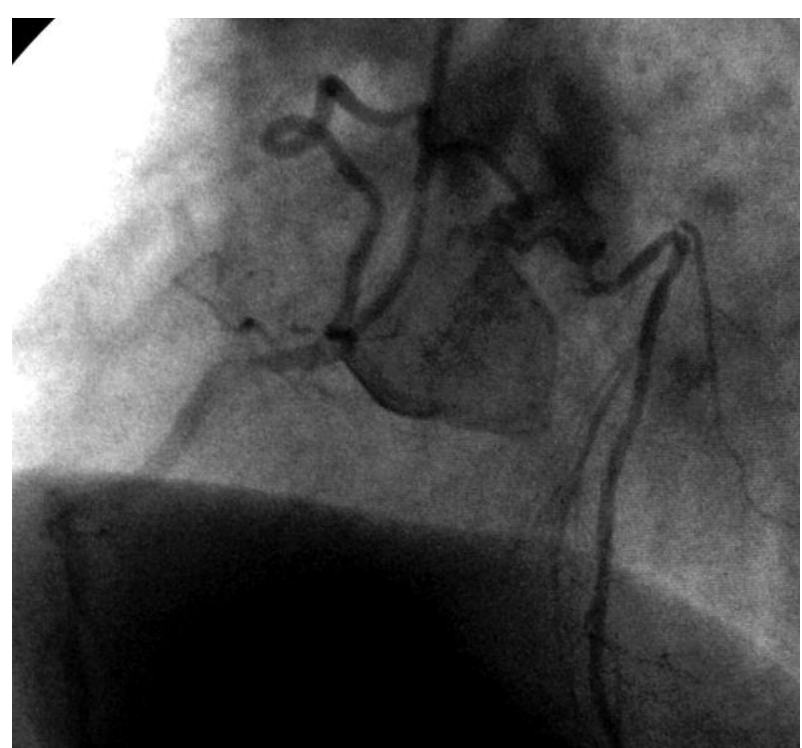

Fig. 2. Collateral circulation from the conus artery to the left anterior descending artery

Ryc. 2. Krążenie oboczne z tętnicy stożka do gatęzi przedniej zstępującej 